\title{
Ирина Поздеева
}

Московский государственный университет им. М. В. Ломоносова

\section{«ВОСПОЙ ГЛАСОМ, ВОСПОЙ ДУХОМ". ДУХОВНАЯ ЛИРИКА СТАРООБРЯДЧЕСКИХ ПОМОРСКИХ ОБЩИН ВЕРХОКАМЬЯ}

Многие страны мира испытывают сегодня влияние двух противоположных тенденций: глобализации - с одной стороны, и поисков национальной идентификации и самоидентификации - с другой. В России это привело к активному стремлению изучить и понять традиционную христианскую культуру, сохраненную общинами старообрядцев, мировоззрение и даже мироощущение которых точнее всего определить как принципиальный традиционализм.

Среди сокровищ духовной культуры, сохраненной сторонниками «старой веры», особое место занимают духовные стихи [Федотов 1991; Kowalska 1987; Никитина 1989].

Они вызваны потребностью выразить глубокие душевные чувства - веру, надежду, любовь, страх божий, раскаяние - в близкой человеку форме: духовной песни, которая, в отличие от светской, уместна и в праздники, и в посты, и после домашней трапезы, и за работой вне дома; духовная лирика в обычной жизни создает и сохраняет молитвенный торжественный настрой души.

Являясь частью традиционной книжности, эти произведения сохранили неразрывную связь с христианской письменной культурой; а став частью устной словесности, выработали самые близкие народу выразительные формы, в которых точнее, чем в других искусствах, передан характер живой народной веры в Господа [Никитина 1989].

Духовные стихи в широком понимании - стихотворные произведения на духовные темы, возникшие в среде народа, или воспринятые им памятники, созданные профессиональными авторами. Для того чтобы отнести духовные стихи к какому-либо жанру или объединить в один самостоятельный жанр, они слишком разнообразны, занимают широчайший диапазон: между церковнославянским языком и местными диалектами русского [Пряхина 2007], между профессиональным стихом и фольклорным, между литургической 
музыкой и народной песней. Эти произведения могут быть и в отношении языка, музыки, характера исполнения и восприятия и даже по функции близки: одни - к текстам богослужения, другие - к песне-плачу, народной лирике или городскому романсу. Являясь частью системы традиционной культуры, которая, как и любая народная культура прошлого, региональна и исторична, духовные стихи для адекватного изучения требуют в качестве источника достаточно полный комплекс духовной лирики исторически сложившегося региона, комплекс, рожденный потребностями его носителей и особенностями их веры, который сложился и обслуживает именно этот регион.

Сегодня мы впервые имеем такой вполне репрезентативный комплекс духовной лирики поморских общин старообрядцев района верховьев Камы, который здесь возник, существует и служит старообрядцам на протяжении трех веков.

Верхокамье - небольшой, достаточно изолированный район у истоков реки Камы, площадью примерно 60 на 60 километров. (Важно обратить внимание на эту цифру, так как богатство культуры этой территории реально можно представить и понять только исходя из крошечных ее размеров). Это район болотистых лесов, глинистых земель, т.н. рискованного земледелия, в котором в 1970-х гг. полностью отсутствовали коммуникации, и транспортные, и информационные. В начале 70-х гг. прошлого века этот район был открыт археографами Московского университета и определен как район, где традиционная культура сохранилась еще как система и где можно было проследить причинно-следственные связи разных явлений этой культуры. До открытия древнего топонима района, упомянутого Симеоном Денисовым в послании 30-х гг. XVIII в., по названию основного районного центра он именовался Верещагинским [Поздеева 1982; Мельчаков 1994; Русских 1999].

В Верхокамье ежегодно в течение 30 лет проводились экспедиции, которые носили комплексный всесторонний характер и ставили своей целью выявить, зафиксировать и изучить все проявления традиционной культуры. В результате этих работ составлены, описаны и частично опубликованы шесть фондов, которые вместе представляют поливидовой архив [Поздеева 2000] крестьянских старообрядческих общин Верхокамья.

Основой, базой традиционной народной культуры является словесность в двух ее формах - письменной и устной. Духовные стихи равно относятся и к той и к другой: они входят в состав местной книжности, поэтому не могут считаться собственно фольклором, хотя их функция - именно устное исполнение.

Источниками предлагаемой ниже работы были два фонда: прежде всего, книжное собрание, составленное в течение тридцати лет полевого изучения Верхокамья. Это полученные для МГУ 359 рукописей XV-XX вв. и около 150 кириллических изданий XVI и первой половины XVII вв. Древнейшими памятниками являются Пролог 1454 г. и анонимная дофедоровская печатная Псалтирь середины XVI века, которая 400 лет использовалась для обучения 
верхокамских детей вере и церковнославянской грамоте. Использованы также описания около 2000 книжных памятников XV-XX вв. (частично сделанные в «поле»). Кроме того, важнейшими источниками стали фонозаписи, выполненные сотрудниками экспедиции в те же годы (сотни часов аудиозаписей всех жанров фольклора и духовных стихов).

Чтобы понять значение и функции духовных стихов был привлечен еще один фонд - полевые дневники, в которых были описаны и расписаны рукописи, не полученные для МГУ, и приведены необходимые сведения о членах общины, в том числе о личных книгах, о традиционном обучении чтению и письму церковнославянских книг, пению. В Фонде полевой документации хранятся более 100 полевых дневников, около двух тысяч страниц записей. Частично для работы привлекался и фонд TV записей, который, к сожалению, активно создавался только с 1993 г., но в нем также зафиксировано исполнение духовных стихов. Четвертый значительный фонд - фотографии (более 2500 кадров с 1972 г.), в котором сохранились снимки многих исполнителей духовных стихов.

Верхокамское рукописное собрание научной библиотеки МГУ описано, и описание опубликовано [Агеева и др. 1994; Поздеева 1996]. В составе более 1000 номеров фонозаписей устной словесности, представлены все жанры фольклора: свадьба с 50 номерами, лирические, трудовые и игровые песни, былички и т.д. Выполнено около 300 часов телевизионных записей, зафиксировавших живой образ людей, богослужение, ремесла, хозяйственную деятельность. TV записи, выполненные в Верхокамье, уникальны, так как беспоповцам обычно категорически запрещено записываться на телевизионную камеру (нам это было позволено только в результате десятилетий полного доверия). Сотрудники Пермского областного краеведческого музея (ныне - Пермский краевой музей), работавшие совместно с нами, собрали в Верхокамье почти уникальную по полноте коллекцию предметов материальной культуры и прикладного искусства. Например, более 100 поясов с 45 орнаментами, изготовленных девятью техниками: тканые, плетеные, вязаные и т.д. Полно представлены различные ремесла, которые обслуживали и сегодня обслуживают строгих поморцев-чашечников. То же самое относится и к индивидуальному хозяйству, которое должно обеспечивать всем необходимым «соборных» членов общины.

Полевые исследования зафиксировали не только памятники традиционной культуры, но и связи различных ее направлений. Опубликовано более 220 научных работ и их библиография (до 2007 г.) [Клюшкина 2008] ${ }^{1}$. Однако едва ли бы все это представляло уникальную ценность, если бы мы не могли объяснить причину высокой сохранности в Верхокамье древних традиций, которую раскрывает история местных старообрядческих общин.

1 В библиографии Клюшкиной из 455 учтенных публикаций Верхокамью посвящены 220. 
Начав в 1972 г. археографическую разведку района, мы столкнулись с тем, что в одних и тех же деревнях жили старообрядцы поморского старовыговского согласия, но называющие себя «дёминцы» и «максимовцы». Они не соединялись между собой в молитве, в браке, трапезе; даже в общину друг друга принимали первым чином крещения, а приходящих из Русской православной патриаршей церкви - вторым. Поиски ответов на вопросы: как, почему и когда раскололась единая поморская община, привели к выяснению, что существует местный документ ("Подлинник”) о разделе. Через три года «детективного расследования» мы нашли соборные решения о разделе и «дёминцев», и «максимовцев» [Агеева и др. 1994: 239; Сморгунова 1982], выяснили, что окончательный разрыв произошел в 1888 г., после 22 лет попыток сохранить единство. В тех же соборных решениях говорилось не только о причинах, но и о географии раздела, которая точно соответствует современным границам расселения «дёминцев» и «максимовцев» в районе. Раскол единой поморской общины произошел из-за ссоры за место пасхальной службы двух наиболее авторитетных наставников; один из них был «запрещен», но этого не признал и продолжал крестить и исполнять иные требы. По имени одного из наставников - Максима Жданова были названы пошедшие за ним «максимовцы»; второе согласие названо по селу, где проходил Собор, - Демино. Поскольку те и другие жили в одних населенных пунктах, вели яростную полемику при фактическом единстве веры, каждая из общин старалась доказать свою «истинность» большей приверженностью к древнему образу жизни².

Таким образом, в конце XIX в. происходит глубокая архаизация и духовной, и материальной жизни поморцев Верхокамья.

Структура всех общин одинакова. Члены общины до и после репродуктивного возраста и люди, отказавшиеся от брачных отношений, могли стать полноправными членами общин-соборов или «соборными», которые системой запретов отделялись от окружающего «антихристова» мира [Мяло 2008]. Они должны были исполнять монашеское правило, были строгими «чашечниками», не могли покупать в магазинах или у людей иной веры продукты, носить современное платье, ездить на машинах, работать в государственных организациях, участвовать в общественной жизни, в том числе, не могли «дьявола тешить» - петь любые светские песни, которые помогали им всю прежнюю трудовую жизнь. В этом одна из главных причин долгого сохранения и богатства здесь традиционной культуры вообще и, в частности, духовной лирики.

Поэтому именно здесь в Верхокамье, мы впервые получили возможность изучить достаточно репрезентативный, региональный, сложившийся исторически комплекс духовных стихов, как часть богатейшей письменной и устной

2 Опубликован замечательный альбом, профессионально и полно представляющий поразительно изящную в своей кажущейся строгости материальную культуру и народно-прикладное искусство поморских общин Верхокамья [Димухаметова 2010; Чагин 2010: 36-54]. 
словесности. При подготовке книги Кому повем печаль мою. Духовные стихи Верхокамья. Исследования и публикаиии И. И. Пряхина [2005: 169-181; 2007: 36-55] выявила 93 текста духовных стихов (в 661 списке) по 80 рукописям (из 359, составляющих Верхокамское собрание ОРКиР НБ МГУ) и 11 стихов, аудиозаписи которых были сделаны, но в рукописях их тексты обнаружены не были. Таким образом, более $90 \%$ текстов духовной лирики имеют письменную традицию. Публикуя все стихи в орфографии подлинника, И. И. Пряхина сверила тексты каждого стиха по другим спискам и привела в публикации все разночтения. Поэтому книга содержит значительный материал для изучения языка верхокамских старообрядцев (значительная часть текста сверена по 10-15 и даже 26 вариантам). Музыкальная характеристика верхокамских духовных стихов принадлежит М. В. Макаровской [2007: 56-65]. Ей удалось выбрать из всего комплекса фонозаписей для публикации 57 стихов, которые записаны в устном исполнении в 65 музыкальных вариантах ${ }^{4}$, в том числе, 11 стихов пришлых, отсутствующих в письменной традиции. Таким образом, опубликованный верхокамский комплекс духовной лирики составляют 104 стиха. Всего М. В. Макаровская обработала около 400 аудиозаписей, сделанных от 45-ти индивидуальных исполнителей и 20 ансамблей. Лучшие исполнители в 70-х гг. могли индивидуально спеть 20-24 стиха [Поздеева 2007: 27-28].

Насколько распространено в Верхокамье было искусство пения духовных стихов, показывает сравнение с иными, несравненно большими по территории и по количеству старообрядческого населения регионами. Экспедиции на Алтае в 16 административных районах и 6 городах также сделали 400 аудиозаписей духовных стихов. В новгородской земле, где достаточно много староверов в таких центрах, как Старая Руса, обнаружено и опубликовано всего 71 стихотворение [Мельников 2011] Усть-Цилемский комплекс стихов, названия которых опубликованы в описании усть-цилемских сборников В. И. Малышевым, состоит всего из 27 единиц [Малышев 1960].

Если говорить об оригинальности местной духовной лирики, то при подготовке к изданию состав верхокамских духовных стихов был сверен с составом 17 публикаций ${ }^{5}$, вышедших с 60-х гг. XIX - до начала XXI в. В результате выяснилось, что 35 текстов верхокамских стихов или их самостоятельно бытующих вариантов, нет ни в одном из этих источников, и только 18 текстов учтены в 2-х и 3-х публикациях.

Духовные стихи Верхокамья уникальны и своим музыкальным богатством. М. В. Макаровская, изучившая все аудиозаписи, их исполнения и выполнившая

${ }^{3}$ Книга вышла благодаря Т. Ф. Самборской.

${ }^{4}$ Несколько записей испорчены из-за плохой техники, другие - не пригодны из-за плохого исполнения.

${ }^{5}$ См. указания о наличии публикации после каждого текста в той же книге «Кому повем печаль мою...» 
все переводы напевов стихов на пятилинейную нотацию, опубликованную в той же книге, пишет: „Жанровый диапазон напевов оказался здесь чрезвычайно широк: от «старых» былинно-повествовательных распевов, плотной вязи гетерофонии и свободной мелизматики - до поздней светской песенности, вплоть до мелодий плясового и частушечного склада" [Макаровская 2007: 61; 2010: 181-197].

Основными источниками музыкальных традиций верхокамской духовной лирики М. В. Макаровская справедливо считает поморское (выговское) литургическое пение и местную крестьянскую песенность; «пришлые» напевы в Верхокамье были перетонированы. Несмотря на широкое сюжетное разнообразие пения, она приходит к выводу о сохранении даже в 70-ых гг. XX в. единого интонационного строя местной певческой традиции, выработанного более чем за два века ранее [Макаровская 2007: 65]. То же представление о единстве традиции возникает и из разнообразия стилей, языка, времени создания и источников текстов духовной лирики Верхокамья, проанализированных, как уже указано, И. И. Пряхиной, которая считает, что особенностью стилистики верхокамской духовной лирики является сочетание (в той или иной пропорции) русского народно-песенного языка, местной лирической традиции и языковых форм церковнославянских произведений [Пряхина 2005: 169-181; 2007: 53]. Много и успешно работала с верхокамской устной словесностью С. Е. Никитина [1989: 149-161; 1992а: 73-79; 1998: 30-36]. По материалам верхокамских аудиозаписей 70-ых гг. прошлого века опубликовала статью музыковед М. Б. Чернышова [1982].

К сожалению, это замечательное духовное богатство в районе уже практически утрачено и сохранилось благодаря вышедшей публикации, которая и является основным источником для данной работы.

Уникальный характер комплекса верхокамской духовной лирики в том, что: во-первых, этот комплекс пока единственный, достаточно полно отражающий, и в диахронном и в синхронном разрезе, духовную культуру старообрядческих крестьянских общин поморского согласия, исторически сложившегося и существовавшего более 300 лет в определенных географических границах района. Во-вторых, мы так же впервые получили обе составляющих этого комплекса - рукописную традицию текстов и устное их исполнение: более 600 текстов стихов в 80 памятниках XVIII-XX вв. и более 400 фонозаписей устного исполнения - 45-ти индивидуальных исполнителей и 20-ти ансамблей. В-третьих, характер и функции духовной лирики Верхокамья можно рассматривать как часть зафиксированной и изученной системы местной традиционной культуры.

Это позволяет нам также впервые, опираясь на указанные исследования, рассмотреть духовные стихи как источник для понимания традиционной веры верхокамского старообрядца-крестьянина, отраженной и зафиксированной в комплексе духовных стихов. Его составляют и «старшие», и новые стихи разного происхождения, но все они выбраны и сохранены местными общинами, и все, в большей или меньшей степени, являлись фактом духовной жизни 
и фактором воспроизводства и сохранения духовных традиций поморского старообрядчества, почти три века живущего у верховьев реки Камы.

В синкретичной культуре средневековой традиции невозможно разделить духовные стихи ни по их содержанию, ни по функциям. Эти тексты, объясняющие, пересказывающие Писание, фактически охватывают все стороны веры и жизни верхокамских общин, отражают особенности вероучения в его местном варианте поморской беспоповской традиции.

Цель нижеследующего анализа - показать характер и глубину живой народной веры, запечатленной в духовной поэзии, отобранной, сохраненной, интерпретированной крестьянами-старообрядцами - носителями древней народной традиции.

Среди наиболее важных с этой точки зрения произведений в районе бытования - «старые» стихи на ветхозаветные темы, в том числе самый любимый и равно популярный и в письменной и в устной традиции - Плач Иосифа, названный Кому повем печаль мою ${ }^{6}$.

Кому повем печаль мою,

Кого призову ко рыданию,

Токмо Тебе, Владыко мой,

Известна Тебе печаль моя.

Моему Творцу-Создателю

И всех благих подателю...

Отче, отче, Иякове

Святыи мой Израилю,

Пролей слезы ко Господу

О своем сыне Иосифе.

Этот стих о страдании, о верности заповедям Божиим, стойкости и праведности настолько популярен в Верхокамье, что сохранился в трех вариантах напевов - самых протяжных - до 11 звуков на один слог. Именно эти, достаточно ранние общерусские стихи стали для нас символом старообрядческой духовной лирики и близости ее к древней традиции; дали название книге публикаций. Мелодия этой духовной песни протяжная, печальная, неспешная и почти трагическая, соответствующая стремлению выплакать горе, плача «день и ночь».

Совершенно иная стилистика и лексика у не менее распространенного и любимого стиха также на ветхозаветную тему - о потопе․․

6 Здесь и далее указываются номера стихов по книге «Кому повем печаль мою...», название стиха, если оно есть в стиховниках и количество выявленных на начало ХХІ в. его списков. (№ 37. “Кому повеем печаль мо”, 9 списков, пелся тремя (!) напевами). В цитируемых текстах учитываются только те особенности орфографии, которые можно передать русской азбукой. Иногда сильно искаженное слово заменяется правильным из аналогичного варианта; пропущенные буквы ставятся в квадратных скобках.

7 № 63. «Cтих о nomone вселенском». Сверен по четырем спискам. Записан в двух напевах. Популярен в исполнении. 
Потоп страшной умножался,

Народ видя, испужалса.

Гнев идет. (трижды)

Видя воды многи люты,

Побежали в горы круты.

Там спастись. (трижды)

Лютость, в кротость примирились

Един с другим не вредились.

Лев с овцой. (трижды)

Ветхозаветный повсеместно распространенный, хорошо изученный стих - Плач Адама, сохранился в Верхокамье в трех вариантах, но все они не поются. Первый вариант найден только в одном списке ${ }^{8}$; второй широко распространен

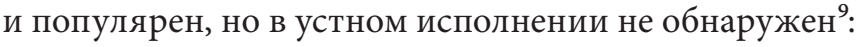

Плакался Адаме перед раем стоя:

О раю мой, раю прекрасный мой раю...

Уже аз не вижу все райския кущи,

Уже аз не слышу архангилска гласа...

Оба стиха чрезвычайно образно описывают состояние людей после грехопадения:
Очи наши - ямы,
Руци наши - грабли:
Что очи завидят,
То руци заграбят.
Что Бог нам дал много,
Нам кажется мало.

Оба стиха завершаются молитвой о спасении и перечислением необходимых для спасения добрых дел. Но краткий и редкий вышеуказанный вариант ${ }^{10}$ продолжает эту ветхозаветную тему уже верой в возможность спасения, данную людям рождением Богочеловека:

Господь родился -

Адам свободился,

Весь мир обновился.

При всем разнообразии сюжетов и тематики верхокамских духовных песен в их комплексе два центра, к которым так или иначе тяготеют большинство

8 № 72. Без заглавия. Один список. Отдел редких книг и рукописей Научной библиотеки МГУ, далее - ОРК и Р НБ МГУ, № 459, л. 9-10. Не пелся.

9 № 64. «Сказание о плаче Адама», сверен по 13 спискам. Не поется.

10 Аналогичный текст известен только в издании «Духовные стихи старинные». Слова и напевы записаны И. И. Заволоко в деревне Войново 20.VII.1936. Рига 1937. С. 4-5. 
текстов. На первом месте в духовной поэзии Верхокамья и по количеству, и по значению, по полноте тематики стихи, трактующие учение о Богочеловеке Христе и излагающие учение Христа о спасении. В стихах, посвященных Рождеству Христову ${ }^{11}$, четко сформулировано понимание его сущности:

Христос днесь родися,

Бог во плоти явися.

Далее, в том же тексте эта тема повторяется, когда описываются события, изображенные в композиции иконы Рождество Христово: вол и осел вместе с пастырями прославляют «Во плоти Бога суща» (повторяется дважды). Содержание стиха близко к тексту службы, фрагмент которой цитируется:

Почиваяй в яслях

Свобождаяй нас всех

Явивыйся во плоти, Боже,

Разумное Солнце (дважды).

Завершение текста - совершенно иного стиля и происхождения - прямо из светских кантов петровского времени:

Виват Тебе вечно, в веки бесконечно,

Виват, Виват, Виват, Христе.

Такая сложная комбинация разных источников, пожалуй, исключение среди духовной лирики Верхокамья. Но более умелые и даже необходимые сочетания характерны для многих текстов. Таков и весь комплекс духовных стихов, объединяющий произведения различного происхождения, времени, стиля, которые вместе создают яркую и образную общую картину живого наследия, восприятия культуры различных традиций.

В стихах о Христе приводится даже хронология пришествия Богочеловека, время его рождения и смерти ${ }^{12}$ :

Пророки пророчили за .а. [тысячу] лет

Другие сказали за .т. [триста] годов,

Во пятый во тысяче в пятистах годах,

Рождение и мучение Исуса Христа

Во марте во месяце во последних днех

Страшныя недели во пятничной день.

Далее излагается картина Распятия, плача Богоматери и обещание, данное Христом, воскреснуть в третий день.

Еще одно стихотворение о распятии Христа обнаружено в 20-ти верхокамских рукописных стиховниках от XVIII до середины XX в. В нем с эмоциональной

11 № 90. «Стих Рождеству Христову». Единственный список. Не пелся.

12 № 81. «Со страхом, братие, мы слушаем». Один список. Пелся. 
картиной крестных мук умело соединена снова краткая и четкая формулировка важнейших положений христианства, вложенная в уста самого Христа ${ }^{13}$ :

Мати, смерть - живот вечный

Я верным даю на спасение

Неверным же - на вечную муку.

Воспоминание о смерти Христа вызвало к жизни одну из самых эмоциональных народных песен-плачей ${ }^{14}$ :

Плачите, стоните, небо и земля,

Плачите, рыдайте, солнце и луна,

Плачите, стоните, месяц со звездами,

Плачите, рыдайте реки и моря,

Плачите, рыдайте, вдовы, сироты,

Наставник и учитель ваш

Покинул вас всех.

В стихах кратко и четко излагается значение крестной смерти и воскресения $^{15}$ :

Ты, Господи,

Прежде нас умре и воскресе,

И нас с Собою воскреси.

В одном из красивейших поздних стихов ${ }^{16}$ ангел сообщает женам-мироносицам весть, обещанную Христом Богородице в стихе О распятии:

Я низпослан небесами

Весть чудесную принес

Нет Живаго с мертвецами,

Гроб уж пуст. Воскрес Христос!

И спешат оттуда жены,

И с восторгом их уста

Проповедиют Сиону

Воскресение Христа.

Оценить краткость и точность языка стихов, рассчитанных на понимание и запоминание, причем речь идет об основных положениях христианской догматики, можно, процитировав текст стиха о тайне причастия, снова вложенный в уста Богочеловека ${ }^{17}$ :

13 № 79. «Стих о распятии Христове». Сверен по 20 рукописям. Пелся.

14 № 81. «О страсти Господа Исуса Христа». Один список. Пелся.

15 № 46. «О Боже, превечныцй, Царь изарем». Один список. Не пелся.

16 № 100. «Стих о воскресении Христове». Пелся. В рукописях не найден.

17 № 28. «Стих о Закхее». Два списка, пелся. Оба сборника, в которые эти стихи вошли, - поморские. 


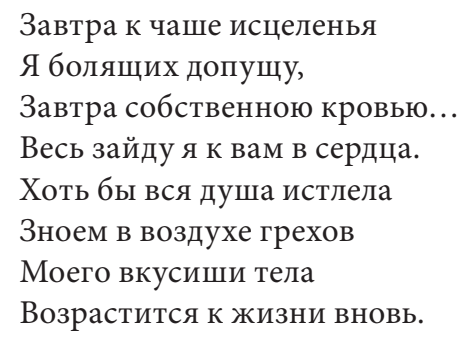

Показательно само достаточно активное существование стихов о причастии в беспоповской традиции Верхокамья, которая никогда не отрицала значения этого таинства, но считала его невозможным в послениконовское время.

В стихах говорится о многих иных сторонах вероучения. Постоянно - о надежде на Господа; заповедь о любви к людям изложена удивительно кратко и точно: «Человеку человека, Творче, Ты велел любить» ${ }^{18}$. Таким же образом изложены в верхокамских стихах и другие положения православия. Их стихотворные формулировки, скорее даже формулы, сразу и навсегда запоминаются, действительно «входят в сердца» слушателей.

Устным Катехизисом или Катехизисом для пения, в вопросах и ответах можно считать широко известные «евангельские» стихи ${ }^{19}$.

$$
\begin{aligned}
& \text { Вы, люди наученные, } \\
& \text { От разумных избранные } \\
& \text { Вы скажите, что есть един. } \\
& \text { Един Сын Марии, } \\
& \text { На небесах царствует, } \\
& \text { Надо всеми Бог. } \\
& \text { Вы, люди наученные, } \\
& \text { От разумных избранные } \\
& \text { Вы скажите, что есть два. } \\
& \text { Два закона Моисеова, } \\
& \text { Един Сын Марии } \\
& \text { На небесах царствует, } \\
& \text { Надо всеми Бог... }
\end{aligned}
$$

Так от пяти до двадцати пяти. В вопросах и ответах изложены основы догматического богословия. При этом каждый ответ повторяет все предыдущие и неизбежно запоминается.

В эсхатологическом восприятии мира, отразившемся в духовных стихах, значительное место занимает учение о рае и аде, интерпретированное народным крестьянским сознанием и эмоционально представленное как противопостав-

18 № 4. Без заглавия. Один список. Не пелся.

19 № 96. «Стих о числах». В рукописях не обнаружен. Популярен в устном исполнении, но поется обычно только текст первых пяти вопросов. 
ление двух картин. Для описания рая используются яркие образы природы в русских сказках ${ }^{20}$ :

Раю, ты раю, прекрасныи, тебе

Сам Господь сотворил есть.

Раю, ты раю пресветлыи, тебе

Сам Господь просветил есть.

Раю, ты саде предивныи,

Тебе сам Господь насадил есть.

В тебе древеса прекрасная

Возрастают и процветают,

Птицы в тебе зело краснии

Пение пречудно воспевают...

В тебе, раю, реки истекают,

Медом и млеком протекают...

Солнце ис тебе восходит

Земля вся концы просвещает.

В этом тексте изложено библейское (в народной интерпретации) представление о вселенной, и чисто крестьянское представление о счастье, даже говорится, что в Раю «постеля мягцы и предивны». Воспевается и духовная красота рая: «Доброта в тебе несказанна, чистота твоя всепречиста, радость неизреченна».

В еще более ярких образах дано народное представление об аде. Десять адских казней описаны в чрезвычайно эмоциональной манере, передающей ужас нераскаявшегося грешника ${ }^{21}$ :

О люте мне грешному

Боюся я Геены, реки огненныя

О люте мне грешному, боюся я смолы кипящия

Боюся я мраза лютаго

Боюся я червия ядовитаго.

Не менее изобразительным является широко известный стих (12 списков и постоянное исполнение) о том, как грешной душе ангелы показывают адские муки ${ }^{22}$ :

Тут смола кипит, да смола кипит да кипучая...

Тут черви гимзят, тут черви гимзят, ядовитыя...

Тут огонь горит, тут огонь горит да велми палит...

Завершается эта страшная картина обещанием грешной душе:

Уж тут тебе, душа, вечно царствованье,

Вечно царствованье, вечно празднованье.

20 № 74. Без заглавия. Сверен по восьми рукописям. Не поется.

21 № 48. Без заглавия. 19 списков. Не пелся.

${ }^{22}$ № 86. Без заглавия. Нач.: Уж на вольном свету душа иарствовала. 
В стихах, как правило, образно и чрезвычайно выразительно изложены действия дьявола, соблазняющего человека, душа которого будет обречена вечным мукам в аду ${ }^{23}$ :
Напал диявол на меня...
Метал сети на пути моем,
Скрежетал на меня зубом,
Аки лютои зми[и],
Подстрелил стрелою греховною,
Попалил мечем грехов моих.

В духовной поэзии Верхокамья говорится и о социальном учении христианства. Здесь популярен общерусский стих о двух Лазарях, в котором изображены муки души богатого и немилостивого ${ }^{24}$. В стихе говорится, что немилостивы ангелы:

Потхватили душинку на востры копья,

Подынули душинку велми высоко,

Отпустили душинку велми глубоко.

Замечательно краткая и удивительно емкая формулировка социального учения изложена в четырехстрочном стихе, аналогичных которому в изданиях найти не удалось ${ }^{25}$ :

Господь нас всех сотворил,

нищих и богатых,

Нищи богатыми питаются,

Богатые нищицками молитвами спасаются.

После этого краткого стиха писец даже написал слово «конец», чтобы читатель не сомневался в завершении текста.

О необходимости милосердия, нищелюбия, милостыни поется во многих стихах. В одном из них ${ }^{26}$ Христос говорит:

Кто бедному в беде не поможет,

Тот упустит и мне услужить.

Важнейшая тема духовной поэзии - спасение души от страшных наказаний грешников в аду. Для этого необходимо, как говорится в стихах, Богу принести три дара: «сердце чистое, веру твердую, надежду великую, так как вера и надежда многих грешных душ спасла, а покаяние - согрешивших к Христу-Богу привело» ${ }^{27}$. В стихах названы основные требования богоугодного христианского

\footnotetext{
23 № 45. «Стих маленькой». 17 списков. Пелся, но не расшифрован из-за плохой записи.

24 № 26. «Два Лазаря». Сверено по шести спискам. Пелся.

25 № 20. «Стихи о нищзих и богатых». Два списка. Не пелись.

26 № 102. «Жду гостя». В рукописях не обнаружен. Пелся.

27 № 82. «Сей стих дорогой». 6 списков. Не пелся.
} 
жития: «Храни любовъ и милость... храни пост и молитву... храни Господа Бога во своем помышлении, храни молитву Его, непрестанно твори ти ю» ${ }^{28}$. В ряде стихов упомянута необходимость бороться с распространенным в Верхокамье грехом - упиваться пивом и вином.

Тема спасения души в духовной лирике неразрывно связана с постоянным напоминанием о смерти «неизбежной», «неумолимой», «неожиданной», «лютой» и наказании за грехи, которые необходимо замаливать при жизни. Этим темам в Верхокамье посвящены десятки стихов:

Не защита от смерти богачество

Не замена от смерти друзи сердечныя

Ни слезами от смерти не отплакатися

А молением от смерти не отмолитися ${ }^{29}$.

В стихах о смерти мы снова находим самую разнообразную стилистику и лексику. Например, это видно если сравнить стих о смерти ${ }^{30}$ и два текстовых варианта стиха: «Всяк человек на земли живет...»” жалобой души: «Ох, увы и горе, почто жила в своей воле». О неизбежной смерти говорится на примерах самых знаменитых исторических личностей: Александра Македонского, Августа, Петра Великого, древних патриархов.

Стихи о смерти полны устрашающих образов, требующих от человека духовной готовности. Особенно популярен в Верхокамье (21 список) указанный выше стих Человек-от живет, как трава растет. Как уже сказано, он существует в двух вариантах, исполняется двумя напевами, записано 26 исполнений. Вот фрагмент одного из вариантов ${ }^{32}$ :

Человек-от живет, как трава ростет,

Человеческой век яко травной цвет,

По утру трава ростет, цвет по вечеру отпадет,

Человеческой ум, яко дым, ветром несет.

В ткань этого стиха естественно вплетены темы Писания: «Не наслышитца Писания, не спасется человек».

Не менее любимы в Верхокамье стихи О горе мне, горе мне $e^{33}$, посвященные той же теме, неизбежности смерти, необходимости покаяния в грехах при жизни. В многочисленных стихах этой тематики перечисляются особенно частые грехи:

28 № 89. Без заглавия. Сверено по 16 спискам. Пелся, но напев не расшифрован из-за дефектов записи.

29 № 93. Без заглавия. 15 списков. Пелся.

30 № 36. «О смертном скончевании». Один список ОРК и Р НБ МГУ. № 459. Не пелся.

31 № 95. «Всяк человек на земли живет. О смерти, глас 7». В рукописях не обнаружен. Пелся. № 91. «Человек от живет...». 16 списков. Пелся.

32 № 91а. Без заглавия. Четыре списка. Пелся.

33 № 75. «О смерти». Три списка. Два варианта напева. 
С другом я вчера сидел, - зрю на смертный предел;

О горе мне, о горе мне великое.

Плоть мою во гроб кладут, а душу же на суд ведут:

О горе мне, о горе мне великое!

Милости не будет там, - не помиловал я сам:

О горе мне, горе мне, горе великое!

Все стихи призывают к покаянию, угрожая адом: «Душа моя прегрешная, что не плачешься ... Скинь одежду грехов своих покаянием. А не скинешь ты грехи свои - ада не мин[у]ешь» ${ }^{34}$. Часто в стихах перечисляются грехи, которые можно передать фразой из того же текста: «Твари, а не Творцу служил». Пути спасения - это ночное моление, земное поклонение, слезы печальные, тихая милостыня, Исусова молитва, Исусов крест. В стихах Размышления ума человеча ${ }^{35}$ описаны два пути человека во Царствие небесное - в «превечною радость» и в ад - «превечною муку», “превечною пропасть”. Вывод стиха очевиден: «Наша - то дорога у Бога в совете».

Эти же темы логично развиваются в стихах-исповедях, также в Верхокамье широко распространенных и очень красивых ${ }^{36}$ :

Я великий грешник на земном пути,

Я ропщу и плачу, Господи, прости...

Помоги мне, Боже, щедрою рукой,

Ниспосли терпенье, радость и покой.

Другая исповедь - «гипербола» звучит в чисто народном стиле $\mathrm{e}^{37}$ :

Сколько на небе звезды,

Столько во мне грехов.

Сколько на земле лесу,

Столько во мне грехов.

Сколько на лесу листов,

Столько во мне грехов.

В стихах постоянно подчеркивается необходимость всегда сохранять надежду на Господа. Надеяться люди должны, как говорится в одном из стихов ${ }^{38}$ : На Господа, на Христа - Царя Небеснаго, и уж на Матерь Божию, да Богородицу, и на Ангела, да на Хранителя, и на Михаила же на Арханьгила, и на Николу же да на Святителя, и уже и на всю силу да на Небесную».

Пантеон близких верхокамским общинам небесных покровителей, судя по стихам, невелик. Небесная церковь представлена кораблем, плывущим по синему

34 № 23. «Стих о дуще». Один список. Пелся.

35 № 76. Стих размышлени[я] ума человеча. Вариант: «Горе мне, увы мне, во младой юности». 10 списков. Пелся.

36 № 97. «На гору Голгофу - стих покаянныя молитвы». В рукописях не найден. Поется.

37 № 77. Без заглавия. Единственный список. Не пелся.

38 № 55. Без заглавия. Пять списков. Пелся. 
морю, в стихе-молитве с постоянным рефреном: «Алилуия, Господи, помилуй»; на корабле «на золотом престоле сам Исус Христос, во корме сидит Предтеча Иоанн... на носу сидит Никола Милостивый... во гребцах-то седят святии Ангели» ${ }^{39}$. В других стихах упомянуты также Иоанн Златоуст и Ефрем Сирин. Стихов, посвященных Богоматери немного, да и те, имея торжественные начала, как «О пречудная Царица, ушь Ты Пречудная Царица, да Богородица»" не упоминают. Однако Дева Мария призывается, упоминается, к ней обращены молитвы многих текстов. Удивляет другое: отсутствие в верхокамской духовной лирике имен даже самых почитаемых святых. Частично это можно объяснить тем, что в Верхокамье очень давно не было вседневного богослужения. Собирались на общинные моления в двунадесятые, некоторые великие праздники и «на потребу». Да и тогда читали, чаще всего, не по Минее, а по Псалтыри Следованной.

Второй центр, к которому тяготеют стихи, определяющий особенности поморской веры, а также жизнь приверженцев этого согласия - учение о воцарении в мире антихриста.

Стихов, посвященных пришествию антихриста и приближению Страшного Суда - много; именно они особенно популярны и в письменной, и в устной традиции. В них прямо утверждается ${ }^{41}$ :
Уж антихрист на земле родился
Ты еси, змий лукавый семиглавной, Изрыкал он свою горкую ярость
По всеи земли, по вселенной.
Все князья, бояра убоялис
Всю его горькую волю сотворяли.

Вера в приход и господство в мире антихриста, подчинения его власти, сразу же диктует два основных положения, от которых зависит весь образ жизни поморских общин. Первое - обостренная эсхатология, вера в скорое Второе пришествие Христа, конец света и Страшный Суд. Отсюда почти во всех стихах напоминания о необходимости постоянной молитвы и покаяния в грехах. В них изложены все

39 № 33. Без заглавия. Один список. Не пелся. № 33.

40 № 53. Без заглавия. Два списка. Не пелся. Эти стихи, скорее всего, отражают воззрения не выговцев, а согласий более крайних воззрений, так как призывают не просто к уходу из мира, а к смерти. И тем не менее, они вошли в местную традицию еще до раскола общины. Один из известных списков этого стиха обнаружен в уже упомянутом выше Сборнике первой четверти XIX в. Интересно упомянуть, что именно в нем мы встречаем фонетическую запись, передающую местное произношение:

Призовите-ко рабыни

Да духовного отца

Здайте хрех[и]

Да хрехи тяшкиё.

В Верхокамье так говорили о тяжелых налогах продуктами.

41 № 61. Без заглавия. Сверен по девяти спискам; два напева, пелся постоянно. 
стороны учения: перечислены все основные виды земных грехов человека, невозможность искупить грехи после смерти, неизбежность наказания грешникам, страшные картины ада. Все эти темы, чисто христианских воззрений, в поморской традиции крайне усилены, подчеркнуты, выходят на первый план.

Во-вторых, победа в мире антихриста возможна, только если Благодать Святого Духа «взята на небо», а это в свою очередь означает исчезновение трехчинной иерархии и истинного священства, невозможность совершения таинств, кроме тех, которые мог, по необходимости, совершать и мирянин - крещения и исповеди; утрачена и возможность совершения таинства брака. Поэтому представители поморского согласия верили, что спасение возможно только при условии безбрачия. Эта тема - одна из центральных в учении поморцев, причина раскола внутри этого согласия, причина вековых поисков решения. В стихах тема требования безбрачия возникает постоянно. Самый прямой и ясный вариант решения - уход в монастырь. В поморском Верхокамье эти стихи также широко распространены. Важнейший путь спасения, который сразу же решает все проблемы: безбрачие, уход из мира, постоянная молитва - уход в прославленную духовной лирикой «пустыню». Здесь, как и в других старообрядческих регионах, бытует несколько хорошо известных стихов о жизни в монастыре, воспевается природная и духовная красота пустыни ${ }^{42}$. В стихах говорится, что монастырь стоит:

Во прекрасной ли во пустынюшке,

Как прекрасен сад: при реке древа,

При древах етех мелкие пташеч[к]и.

Они раиския поют песенки,

Утешают же они иноков.

Окружающая природа помогает спасению: «труды любить преобразует, легкость отлучает», даже кукушка вместе с иноком «умиленные слезы проливает». В одном из самых популярных здесь стихов о пустыне говорится ${ }^{43}$, что все роды святых восхваляют пустынников:

И Аггели отцем помогают,

Апостоли отцев ублажают,

Пророцы прославляют

И мученицы величают.

Завершается это восхваление отцев-пустынников просьбой:

О, прекрасная пустыня,

Приими мя, яко мати свое чадо!

Научи мя на все благо. Аминь.

42 № 42. Без заглавия. Два списка. Не пелся.

43 № 51. «Стих о прекрасной пустьне». 23 списка. Поется. 
Среди стихов этого содержания в верхокамской книжности сохранились два стиха, связанные с Иоасафом царевичем. Один из них - чисто книжный ${ }^{44}$ и очень популярный; его язык явно претерпел попытки сближения с русским народным; второй ${ }^{45}$ - также в основе своей книжный, короче и менее популярный.

Однако, в Верхокамье, где проблема ухода из мира решается уже иначе - путем разделения, как говорилось выше, общины на «соборных», которые отделяются от мира системой строгих запретов, и «мирских», распространены стихи о пустыне совершенно иного содержания. Например, рассказ отступника, который с «надеждою терпел» лишения, пока был молод: «болотную воду пил, хлеб вкушал ячменный, иногда с корой», а в «зрелых летех» вернулся в мир ${ }^{46}$. В другом иронически рассказывается о монастырском образе жизни ${ }^{47}$ :

В меру щи и кашу поставляют,

За велико почитают.

Пирошка кусок дадут...

Раз в неделю испекут.

По кусочку раздадут,

Как будто просвиру.

В результате «младый инок» «з горя, с досады» идет «искать отрады в деревню за лесок». Как под сосенкой зеленой ${ }^{48}$ песня-жалоба инока, изгнанного из монастыря. Стих посвящен тяжелой жизни в пустыни, которая заключается, прежде всего, в трудностях духовных. Этой теме посвящен стих Идет инок по дороге $e^{49}$ - слезная мольба к Господу, обещавшему вернуть иноку все его потери: дать ангелахранителя, который будет помогать в борьбе с «младыми мыслями« и «злыми помыслами»; написать и дать затерянную «златую книгу», вернуть брошенный в море «ключ церковный». Мы видим, как образы сказки естественно входят в духовный стих-плач и получают новое символическое значение.

44 № 52. «Стих Иоасафа Царевича индииския земли», вариант заглавия: «Стих покаянен зело душеполезен Иосифа (!) Царевича велик судит (!?), глас крат[к]ий». 15 списков. Не пелся. Очевидно, именно из этого текста взяты слова, завершающие вышеприведенные стихи «О прекрасной пустыне». В стихах же Иоасафа они текст начинают:

О прекрасная пустыня,

приими мя в свои частины,

Яко мати чадо свое,

Научи мя на все благо.

45 № 67. «Стих Иоасафа изаревича индииския».

46 № 6. «Стих о юном пустыннике». Два списка. Пелся. В тексте стиха, кроме приведенных, есть прекрасная деталь, которую можно увидеть в любом доме: в стихе бывший инок пишет, что «... лестовку я оставил, на крючок повесил».

47 № 68. «Младый инок». Два списка. Пелся.

48 № 35. Без заглавия. Два списка. Пелся.

49 № 30. «Идет инок по дороге». Не пелся. 
Воззрения поморского согласия на безбрачие, «девство» как на обязательное требование к членам общины в более раннее время, объясняют очень большое количество стихов посвященных этим темам: О девственницы, невесты Христа, Пишет нам, братья, Ефрем Сирин со слезами, Чудная Царииа Богородииа, Во миру жила девица, Где изветочек тот прекрасньй, что долину украшал, Куда агница девалась и ряд других. Однако в большинстве из них, хотя и говорится об уходе из мира «девицы», речь идет, прежде всего, о судьбе «старой веры» - также гонимой и скрывающейся. Многозначность и символичность - одна из традиционных черт духовной поэзии старообрядчества, и этими качествами многие духовные стихи близки литургическим текстам.

В стихах подчеркивается, что именно любовь к женщине - одна из важнейших причин власти антихриста над людьми ${ }^{50}$ :

Овыи антихриста познавают,

А жен ради тому колена поклоняют.

Тако сие житие прельстило,

Яко клеем, к жене и чадом прилепило.

Эта тема возникает многократно. Даже говорится: «Господня печаль в Царство ведет, а женская печаль - в муку влечет» ${ }^{51}$.

Тема брака постоянно оставалась самой животрепещущей в идейных поисках поморцев, затем и отделившихся от них филипповцев и федосеевцев, также имевших определенное влияние в Верхокамье. Стихи даже отразили споры о необходимости отказа от совместной жизни и покаяния так называемым «староженам». Очень четко звучит эта мысль в упомянутых выше стихах «Пишет нам Ефрем Сирин» ${ }^{52}$

Уж конец наш блиско...

Женивыя, раженитися,

Не женивыя, не женитися.

А женитца - вечно погубитца...

Вера в приход и господство на земле антихриста означала особую силу эсхатологических ожиданий. Тема близкого и неизбежного Страшного Суда буквально пронизывает духовную поэзию поморских общин. Естественно, эта тема неразрывно связана с темой смерти и покаяния ${ }^{53}$ :

Востанемте, братие, востанемте,

Востанемте, Богу помолимся.

Век у нас, братие, скончевается,

А Страшный Суд готовится.

\footnotetext{
50 № 103. «Оразделении церкви при Никоне патриархе». В письменной традиции отсутствует. Пелся.

51 № 47. «Книга евангельских бесед от Луки. Похвала девственником». 10 списков. Пелся.

52 № 56. Без заглавия. Один список. Не пелся.

53 № 14. Без заглавия. Семь списков. Пелся.
} 
В другом тексте говорится ${ }^{54}$ :

Идут лета сего света,

Приближается конец века.

В стихе, так и названном Стих о Страшном Суде ${ }^{55}$, рисуются картины Второго Пришествия и гибели мира. Эти темы постоянно звучат, как аргумент, обращение к каждому, призыв к покаянию и праведной жизни.

Следовало бы ожидать, что при таком богатстве и разнообразии содержания верхокамской духовной лирики мы найдем здесь, пожалуй, самые известные старообрядческие стихи - В Даурии дикой - о протопопе Аввакуме, и Боярыня Морозова - но их не оказалось ни в письменной, ни в устной традиции. Зафиксированы в Верхокамье произведения выговские: например, По грехом нашим на нашу страну ${ }^{56}$. В шести списках в местных верхокамских рукописях обнаружен чисто книжный стих с названием Ceu cтuх [на погребение] Андрея Дионисъевича ${ }^{57}$, чаще в литературе он называется по первым строчкам:
Европа, ты славнеиша
мужа сего изнесоша,
В Российском царстве хранящи,
В поморских краях держащи.

Структура стиха близка к построению жития, включает заголовки: Деяния (в том числе говорится: «Киновии две согради, аки красны вертогради»); в разделе Преставление указывается возраст Денисова (56 лет); в небольшом разделе Помяновение, иноки молят:

Тем же молим Ти ся, Боже

Покои душу в райском ложе,

Сего верного Ти раба,

Война церковного храбра.

Таким образом, в стихах не только достаточно подробно и четко в форме самой близкой, понятной и запоминающейся представлены важнейшие постулаты христианства; они достаточно подробно отражают именно поморскую, выговскую традицию беспоповства, но в более крестьянском, если так можно выразиться, «периферийном» варианте.

Живой и открытый характер традиции духовной лирики Верхокамья доказывает наличие достаточно поздно созданных стихов - например, о Федоре

\footnotetext{
54 № 31. Без заглавия. 14 списков. Пелся.

55 № 62. «Стих о Страшном Суде». Один список не пелся.

56 № 58. «Плач пустынножителей соловец̧ких». Один список. Пелся. См. № 57. «Стих о смущении верыљ». 15 списков. Пелся. Считается стихом бегунов-странников.

${ }^{57}$ № 25. «Сей стих на погребение Андрея Денисъевича». Шесть списков. Не пелся.
} 
Гучкове ${ }^{58}$. В верхокамском сборнике духовных стихов - 10-20 гг. ХХ в. ${ }^{59}$ среди классических, широко распространенных текстов под № 17 записан стих, названный Настоящее и прошлое, к годовщине 17 апреля 1905 года ${ }^{60}$. Содержание этих стихов передает фраза: «Теперь, хотя оковы пали, но слезы все блестят в глазах», так как весь стих - воспоминание о страшных временах прошлых гонений.

Очевидно, самый поздний стих в верхокамском комплексе - реакция на новые страшные гонения на веру и верующих, возможно, написан в 30-х гг. $\mathrm{XX}$ в. и передает непреклонную стойкость старообрядцев ${ }^{61}$ :

Пущай нас гонят в Туркестаны
Пущай на север заточат,
Сошлют в Сибирь, в другия страны
Или на смерть приговорят.
Но наше счастье не отнимут,
Оно внутри нас завсегда.
Изгибнет мир и все изгибнет,
Но нашо счастье - некогда.
Оно сокрыто в нашом духе,
В любви и вере во Христа,
Другия счастья злыя сухи
Вся жизнь без етаго пуста.

Духовная лирика общин Верхокамья вовсе не чужда интереса к Русской истории и боли за судьбы России. Один из «старших» популярных в Верхокамье стихов О убиении Бориса и Глеба ${ }^{62}$, сохранил эпический, былинный напев. Стих прославляет князей-мучеников как защитников земли Российской, заступничество молитвы святых князей «сыновом русским поможение от варварскаго нахождения». Их молитвами «Россия вся спасается».

Совершенно иное отношение к Русскому государству XX в. - оно вызывает сожаление и воспоминания о прошлой славе ${ }^{63}$ :

Расширялись наши грани,

Как на пир мы шли на сечь,

58 № 60. «Стих об изгнаннике Гучкове». Два списка. Пелся.

${ }^{59}$ Верхокамские рукописи. № 1541/2. С. 152. Сборник духовных стихов. Полуустав известного местного писца Григория Бисерова.

${ }^{60}$ № 13. «Настоящее и прошлое, к годовщине 17 апреля 1905 года». Один список. Пелся.

${ }^{61}$ № 69. Без заглавия. Один список, рукопись втор. пол. ХХ в. ОРК и Р НБ МГУ. № 1576. Фрагмент стиховника. Особенно тяжелый урон старообрядческие общины понесли здесь после страшного по своей жестокости, возможной, очевидно, только во время Гражданской войны, Сепычевского восстания 1918 г., и его не менее жесткого подавления.

62 № 16. «Об убиении Бориса и Глеба». 15 списков. Пелся.

${ }^{63}$ № 78. «Стих об общем пленении». Два списка. Исполнялся двумя напевами. 
Цари наши брали дани

Сокрушали вражий меч...

Победы достигались не столько мечом, сколько «действом крестной благодати», отринутой современностью. Замечательно ироническое завершение этого стиха, передающее традиционное отношение старообрядчества к светской науке:

Ныне люди только знают посмеяться старине

Звезды на небе считают, царство видят на луне,

Видят там леса и горы, степи, реки, всякий злак,

Не проникнут их лишь взоры, есть ли кофе да табак...

Вся земля крутится с нами, верь не верь на их слова,

Ночь - все мы вверх ногами, днем лишь к верху голова.

В стиховнике конца XIX в. найден единственный список сатирического чисто литературного явно стилизованного стиха: Никон. Дела давно минувщих дней, преданья старины глубокой ${ }^{64}$. В нем подробно говорится об исправлении книг, чинов и уставов богослужения, что и послужило началом раскола Русской православной церкви. Упоминается и отмена земных поклонов, троеперстное перстосложение и другие нововведения. Этим же событиям посвящены еще несколько пространных стихов с изложением реформ Никона в понимании старообрядцев. Стих О разделении церкви при Никоне патриархе, чрезвычайно резкий, в Верхокамье - «пришлый» - в книжной традиции отсутствует, но пелся ${ }^{65}$. Этот, пожалуй единственный текст, в котором автор оставил послесловие, подражая древним писцам:

Писати стихи кончаю

И любовию запечатлеваю.

Прошу люботрудне прочитати

И нашу худость не зазирати.

В этом произведении интересно отношение автора к ряду исторических фактов, например, по его мнению, воцарение Петра I знаменует полную победу антихриста, резко порицается запись «в раскол»; особо подчеркивается роль Петра I в уничтожении российского благолепия:

А когда весь мир прельстился

Тогда и Петр первый воцарился.

Во всю Россию манифесты издавал....

Вси в записи в ревизии пали,

Именем раскольничим себя записали.

Хотя в Верхокамье зафиксировано только 104 стиха, в одной статье невозможно даже перечислить все отразившиеся в них темы, настолько широка функ-

${ }^{64}$ № 59. Один список. Пелся.

65 № 103. «О разделении иеркве при Никоне патриархе». Один список. Пелся. 
ция этого уникального явления традиционной народной культуры. Духовная лирика призвана не только воспеть Господа, но и умолить Его спасти души певцов, научить исполнителей и слушателей богоугодной жизни. Исполнение духовных песен очищает душу и певцов, и присутствующих, позволяет им ощутить единство людей на земле, приблизиться к силам небесным. В беспоповских общинах духовные стихи выполняют функцию определенной «паралитургики». Не менее важна функция «учительная» - стихи учат пониманию веры, покаянию; они являются вместе с книгой важным инструментом сохранения и передачи традиции.

В самих стихах содержится и высокая оценка и формулировка функции духовной поэзии, в определенном смысле эти тексты - рефлексия духовной лирики. Как и большинство иных тем, изложены эти тексты и литературным и чисто народным языком. В стихе ${ }^{66}$, связанном с именем Иоасафа царевича, говорится:
Воспой в песнех Ему приличных,
Сам ходя во древесах.
Воспой гласом, воспой духом
Воспой милость всю Его.

В том же ключе и стиле звучит и призыв другого стиха литературного происхождения ${ }^{67}$ :

\section{Вы певцы мои златоструиныя, \\ Воспевайте песни пресладкия \\ Как органами возглашающе.}

Те же мысли, но совершенно иначе звучат в стихе, прославляющем младенца-Христа ${ }^{68}$ : Пойте сладко пение, пойте стихотворение.

В стихах ${ }^{69}$, широко популярных в Верхокамье, среди грехов названо то, что умерший «не пел песни и пса[л]мы со духов[ны]м со отцем». Та же мысль изложена и в другом тексте: Не воспех бо аз живущии песни духовныя.

Все это позволяет утверждать, что духовная лирика рассматривалась поморцами как обязательная форма служения Господу, а отсутствие в жизни верующего этой формы прославления Господа и покаяния считалось грехом.

Эти тексты и наши полевые наблюдения позволяют считать, что пение духовных стихов было в старообрядческом Верхокамье не просто широко распространенным, а скорее, всеобщим. Очевидно, это одна из причин его столь высокой сохранности.

66 № 92. «Стих Иоасафа изаревича». Два списка. Пелся.

67 № 42. Без заглавия. Два списка. Не пелся.

68 № 29. Без заглавия. Сверено по трем рукописям. Не пелся. Стих уникальный, так как вторую строку: ты мой раи - предписывается повторять пять (!) раз.

69 № 91. Без заглавия. 16 списков. Пелся; № 91а. Без заглавия. Пять списков. Пелся. 
Язык, напевы и происхождение духовных стихов Верхокамья представляют формально разные традиции: церковнославянскую литературную, литургическую, литературную русскую, местный диалект; литургическое церковное и литургическое выговское пение, лирическую песню, городской романс, даже ритмы военной и плясовой песни. Точно так же и происхождение составляющих комплекс текстов и ранних, и поздних стихов различно: это и общерусская христианская лирика, выговские произведения, так называемые «московские стихи» из печатных московских стиховников начала XX в.; стихи, пришедшие из других старообрядческих согласий; в том числе в репертуар верхокамских поморцев вошли стихотворения адептов старообрядческой Церкви, бегунов-странников, и даже произведение секты «субботников». Однако все эти стихи стали фактом и даже фактором жизни поморских общин Верхокамья, как правило претерпев влияние местного произношения, переинтонированные, понятые и воспринимаемые как свои, что подтвердили и их многочисленные исполнения и списки. Деминцы в начале XX в. приняли несколько новых «московских» напевов, максимовцы признавали только традиционные мелодии, но репертуар у тех и у других был в сущности один, так как и вера и структура общин и устав соборных у них были едины. И весь комплекс духовных стихов, складывавшийся, пополнявшийся и что-то утрачивающий (это видно из состава более ранних рукописей) почти три века практически для всего региона был единым. (Однако лучшие певцы и лучшая традиция исполнения в первое десятилетие полевых работ была отмечена в более отдаленном от современных коммуникаций и изолированном Кезском районе Удмуртии).

Важно подчеркнуть, что столь исключительное в XX в. богатство духовной лирики небольшого района, необычное даже для старообрядческих центров, с точки зрения местной традиционной культуры старообрядческих общин, не представляется чем-то особенным. В Верхокамье также богата и разнообразна книжность - более 2200 памятников, из которых свыше половины датируются XV - первой половиной XVII вв. Здесь удалось записать в те же 70-80 гг. всю палитру фольклорных жанров, свадьбу (50 номеров), лирические, игровые, военные и даже плясовые песни.

Необходимость обеспечивать жизнь «соборных» позволила сохраниться десяткам ремесел, в том числе и сегодня живо удивительного мастерства и красоты ткачество, демонстрирующее безупречное искусство подбора цвета и формы.

В 70-х гг. мы могли зафиксировать местную традиционную культуру как систему, структуру и состав которой определяли характер беспоповской выговской веры, а богатство и сохранность ее до наших дней, очевидно, связаны с расколом единой поморской общины на деминцев и максимовцев.

Сталкиваясь с богатой традиционной духовной и материальной культурой Верхокамья и с удивительно близкими нам людьми, ее сохраняющими, участники полевых работ неизбежно попадали под их спокойное обаяние, 
а духовные стихи в исполнении верхокамских поморцев нас буквально завораживали. Трудно представить, чтобы любой непредвзятый наш современник мог остаться к ним равнодушным, ведь эти духовные песни поются не только гласом, но и духом, то есть сердцем, и сердцем воспринимаются.

\section{ЛИТЕРАТУРА}

Агеева Е.А., Кобяк Н. А., Круглова Т. А., Смилянская Е. Б., 1994, Рукописи Верхокамья XV-XX вв. в библиотеке Московского университета, Москва.

Дим уха ме тов а С. А., 2010, Мир вещей русских крестьян ХІХ-ХХ веков. Традиционная народная культура русского старообрядческого населения Верхокамья. Каталог, Пермь.

Кл юш к ина И. В. (сост.), 2008, Научные публикации археографов МГУ им. М. В. Ломоносова и участников комплексных полевых исследований 1968-2007 г2., [w:] Традииионная книга и культура позднего русского Средневековья: история, книжность и культура русского старообрядчества, ч. 2, Ярославль, с. 321-368.

Макаровская М. В., 2007, Напевы духовных стихов Верхокамья, [w:] И. В. Поздеева (ред.), Кому повем печаль мою. Духовные стихи Верхокамья. Исследования и публикации, Москва, с. 56-65.

Макаровская М. В., 2010, Напевы духовных стихов Верхокамья, [w:] Традиционная народная культура русского старообрядческого населения Верхокамья. Каталог, Пермь, с. 181-197.

Малышев В. И., 1960, Усть-Цилемские рукописные сборники XVI-XX вв., Сыктывкар.

Мельчаков В. Г., 1994, Верещзагино. История города и района, Пермь.

Мельни иов И. А. (ред.), 2011, „Ой вы, братья мои, сестры...” Духовные стихи староверов Новгородской области, Москва-Великий Новгород.

Мя ло К. Г., 2008, Традиционная община в историческом времени: реликт или альтернатива, [w:] Традииионная книга и культура позднего русского Средневековья: история, книжность и культура русского старообрядчества, ч. 2, Ярославль, с. 86-99.

Ники тин а С. Е., 1989, О взаимоотношении устных и письменных форм в народной культуре (на материале полевых исследований старообрядиев), [w:] Славянский и балканский фольклор. Реконструкиия славянской духовной культурь: источники и методы, Москва, с. 149-161.

Ники тина С. Е., 1991, Послесловие, [w:] Г. П. Федотов, Стихи духовные. Русская народная вера по духовным стихам, Москва, с. 137-153.

Ни и и тина С. Е., 1992, Устная народная культура и языковое сознание, Москва.

Н ик и тина С. Е., 1992а, “Народная филология” в старообрядческой культуре, [w:] Личность. Книга. Традиция (Мир старообрядчества, вып. 1), Санкт-Петербург, с. 73-79.

Ники и ина С. Е., 1998, Исследование устной культуры старообрядчества: итоги и перспективы, [w:] Живые традииии: результаты и перспективы комплексных исследований русского старообрядчества (Мир старообрядчества, вып. 4), Москва, c. $30-36$. 
Ковальченко И. Д. (ред.), 1982, Русские письменные и устные традиции и духовная культура (по материалам археографических экспедиций МГУ 1966-1980), Москва.

Позде ев И. В., 1982, Верещзагинское территориальное книжное собрание и проблемы истории духовной культуры населения верховьев Камы, [w:] Русские письменные и устные традиции и духовная культура (по материалам археографических экспедиций МГУ 1966-1986), Москва, с. 40-71.

Позде ев а И. В., 1996, Продолжение традиции. Книжная культура старообрядиев Верхокамья, [w:] Книга. Традиция. Культура (Мир старообрядчества, вып. 3), Москва, c. 6-45.

Поздеева И.В., 2000, Поливидовой территориальный архив Верхокамья: история формирования, состав, перспективы сохранения и использования (результаты комплексных экспедиций МГУ им. М. В. Ломоносова 1972-1998), “Отечественные архивы”, № 4, с. 24-35.

Поздеева И. В. (ред.), 2005, Традиционная культура Пермской земли. К 180-летию полевых исследований Верхокамья (Мир старообрядчества, вып. 6), Ярославль.

Поздеева И. В., 2007, Кому повем печаль мою, [w:] И. В. Поздеева (ред.), Кому повем печаль мою. Духовные стихи Верхокамья. Исследования и публикачии, Москва, с. 13-35.

Поздеев а И. В. (ред.), 2008, Традиционная книга и культура позднего русского Средневековья: история, книжность и культура русского старообрядчества, ч. 2, Ярославль.

Пряхина И. И., 2005, Язык духовных стихов Верхокамья (на материалах рукописей Верхокамского собрания ОРКиР НБ МГУ им. М. В. Ломоносова), [w:] Традиционная культура Пермской земли. К 180-летию полевых исследований Верхокамья (Мир старообрядчества, вып. 6), Ярославль, с. 169-181.

Пря хина И. И., 2007, Церковнославянская традиция и диалектные особенности духовных стихов Верхокамья, [w:] И. В. Поздеева (ред.), Кому повем печаль мою. Духовные стихи Верхокамья. Исследования и публикации, Москва, с. 36-55.

Русских Б. К., 1999, Кезский район. Страницьь биографии, Ижевск.

Сморгун нов Е. М., 1982, Пермская рукопись ХІХ в. «О разделе» (ОРКиР НБ МГУ № 1996), [w:] Русские письменные и устные традиции и духовная культура (по материалам археографических экспелииий МГУ 1966-1986), Москва, с. 247-265.

Толстой Н. И., 1991, Несколько слов о новой серии и книге Г. П. Федотова «Стихи духовные», [w:] Г. П. Федот то , Стихи духовные. Русская народная вера по духовным стихам, Москва, с. 5-9.

Федо тов Г. П., 1991, Стихи духовные. Русская народная вера по духовным стихам, Москва.

Чагин Г.Н., 2010, Заселение, материальная культура и быт русского населения Верхокамья, [w:] С. А. Димухаметов а, Мир вещей русских крестьян ХІХ-ХХ века. Каталог, Пермь, с. 36-54.

Чернышова М.Б., 1982, Музыкальная культура русского населения Верхокамья, [w:] Русские письменные и устные традиции и духовная культура (по материалам археографических экспелииий МГУ 1966-1986), Москва, с. 127-150.

Kowalska H., 1987, Rosyjski wiersz duchowny i kultura religijna staroobrzędowców pomorskich, Wrocław-Warszawa-Kraków-Gdańsk-Łódź. 


\title{
«ВОСПОЙ ГЛАСОМ, ВОСПОЙ ДУХОМ» \\ SPIRITUAL LYRIC POETRY OF OLD-BELIEVERS POMORS COMMUNITIES INHABITING UPPER KAMA RIVER
}

\begin{abstract}
The article contains broad discussion of well-preserved traditional Christian culture in the community of Priestless Old-Believers of the 'Pomortsy-Vygovtsy' faction located at the springhead of Kama River. The community of the Kama Old-Believers is situated on a small area ( $60 \times 60$ kilometers) where numerous oral and written relics of spiritual culture were found by the Moscow State University archaeographers. Unique richness and good preserving of a spiritual poem results from the division of the community in the middle of the $19^{\text {th }}$ century into two groups - 'dyomintsy' and 'maximovtsy' for personal and geographical and not doctrinal reasons. Each group despite unity of faith tried to be more religious and better preserve their tradition. The introductory part contains general description of the lyrics which are the result of spiritual life of the Old-Believers community as well as detailed discussion of the research work and publications devoted to Kama Old-Believers. What follows is a deep analysis showing the character, depth of faith and preserving traditions which are included in the spiritual poetry of people working the soil who are directly connected with nature. Significant space devoted to quoting the proems and discussing the essence of numerous spiritual lyrics in the analytical frame proposed by the author.
\end{abstract}

Słowa kluczowe: staroobrzędowcy, bezpopowcy, wiersz duchowny, górny bieg rzeki Kamy, kultura tradycyjna.

Keywords: Old-Believers, the Priestless, spiritual poem, Upper Kama River, traditional culture.

Ключевые слова: старообрядцы, беспоповцы, устная словесность, духовный стих, Верхокамье, традиционная культура. 